Instructions for authors, subscriptions and further details:

http://rasp.hipatiapress.com

\title{
List of Reviewers 2014
}

Date of publication: July $30^{\text {th }}, 2015$

Edition period: July 2015 - January 2016

To cite this article: (2015). List of Reviewers 2014. Research on Ageing and Social Policy, 3(1), 88. doi: 10.17583/rasp.2015.1667

To link this article: http://doi.org/10.17583/rasp.2015.1667

\section{PLEASE SCROLL DOWN FOR ARTICLE}

The terms and conditions of use are related to the Open Journal System and to Creative Commons Attribution License (CCAL). 
RASP - Research on Ageing and Social Policy Vol. 3 No. 1

July 2015 p. 88

\section{List of Reviewers 2014}

We deeply appreciate reviewers' contributions to the quality of this journal during 2014. Yours sincerely,

Alfredo Alfageme

Luis Ayuso

Editors

Aguilar-Hendrickson, Manuel

Cesareo, Vincenzo

Clemente, Rosana

García-Pastor, Begoña

Gilleard, Chris

Hjälm, Ana
Krekula, Clary

Noriega, Cristina

Rofman, Rafael

Viñado, Celia

Walker, Alan C.

Wilinska, Monica 